\title{
长江特大洪水成因与减灾措施*
}

\author{
李曾中 \\ (中国气象科学研究院, 北京 100081)
}

\begin{abstract}
提 要 本文对汛期长江流域特大暴雨及洪涝成因进行了分析, 认为与越赤道气流异常及 受 “非亚支宏观气流系统” 的影响有关. 同时指出, 长江流域的特大暴雨及洪涝灾害不但可以 预测, 并且能够采取措施予以减弱.
\end{abstract}

关键词 特大暴雨及洪涝灾害 越赤道气流异常 非亚支宏观气流系统 减灾措施 分类号 P331.1

中国地处东亚季风区域, 夏季汛期降水受东亚季风与印度季风双重的影响, 因此变率 极大 ${ }^{[1]}$. 1931、1954、1998、1999 年长江流域均出现过历史上少有的特大洪涝灾害, 给中 国造成生命与财产的巨大损失 ${ }^{[2]}$. 李宪之在他早年在德国留学时所做博士论文 “东亚寒潮侵 袭的研究” 中, 就曾指出北半球的冷空气, 可以穿越赤道, 并在南半球的雅加达及澳洲北 部的达尔文港造成特大暴雨 ${ }^{[3]} .1987$ 年在《降水问题》中, 他提出了 “宏观系统” 的概念, 指出冬半球冷空气的侵袭, 是造成夏半球特大暴雨的重要原因 ${ }^{[4]}$.

利用 NCEP / NCAR1979-1995 年再分析格点风资料, 分析了越赤道气流与中国大陆地区 降水的关系，发现东半球夏季 $850 \mathrm{hPa}$ 越赤道气流总量的多塞与中国大陆有代表性的 336 个站 6-8 月平均降水量确实有着密切的关系 ${ }^{[5]}$. 而五月份越赤道气流的强弱又可作为当年 夏季越赤道气流总量多寡的一个预测指标. 利用地磁场异常资料, 可以预测出未来洪涝灾害 发生的地区. 并创立了 “气象与地球物理综合法” 进行了预报试验, 1998-2002 年五年的平 均评分按照国家气候中心的评分标准，达到 73.30 分.

\section{1 越赤道气流异常与中国汛期降水}

李曾中等人对东半球对流层低层越赤道气流通道及其与中国夏季天气关系进行的分 析表明, 越赤道气流的活动状况, 可以较好地表征出东半球夏季风的活动特征, 并与中国 降水关系极为密切 ${ }^{[6-8]}$. 本文利用 NCEP / NCAR1979-1995 年的再分析格点资料, 分析了各年 夏季 (6-9 月) 东半球 $850 \mathrm{hPa}$ 上的越赤道气流总量 $E$ 值, 发现它们与全国有代表性的 336 个站, 6-8 月平均降水量 $R_{336}$ 有很好的相关关系（见图 1). $E$ 值指在 $850 \mathrm{hPa}$ 赤道上每 $5 \times 5$ 网格点上的南风值 $V_{+}$相加的总和 (单位为: $\mathrm{m} / \mathrm{s}$ ). 即 $E=\sum_{0^{\circ}}^{180^{\circ} E} V_{+}(6-9$ 月); 也就是说, 如

\footnotetext{
*2003-07-08 收稿; 2003-12-06 收修改稿. 李曾中, 男, 研究员, emai1:hhz19712@sina. com.
} 
果夏季东半球对流层低层越赤道气流较强的话, 那么当年夏季中国大陆的降水就偏多; 反 之亦然.那么, 如何来对越赤道气流总量 $E$ 值进行预估呢? 分析表明：如果 5 月份越赤道气 流较活跃，那么当年 6-9 月的越赤道气流总量 $E$ 值也就较大.为了表征 5 月份越赤道气流活 动的状况，我们定义了一个五月份越赤道气流的活动特征量: $E_{5}=\sum_{5 \text { 月1 }}^{311}\left[V_{+}\left(120^{\circ} E \sim 180^{\circ}\right)_{\text {max }}+V_{+}\left(45^{\circ} \mathrm{E}\right)\right]$; 其中第一项为 $120^{\circ} \mathrm{E}$ 以东 (到 $180^{\circ}$ ) 各网格点上最 大的一个南风值, 第二项为 $45^{\circ} \mathrm{E}$ 处南风值.利用 1979-1995 年 NCEP / NCAR 再分析格点 资料, 我们分析了 $\mathrm{E}_{5}$ 与 $\mathrm{E}$ 值的年际变化相关直方图如图 2 所示.

从图可以看出，除 1987-1990 年期间不太理想外，两条曲线基本有相同的变化趋势.因 此我们可以说，利用五月份越赤道气流特征量 $\mathrm{E}_{5}$ 值，是可以预估出当年中国大陆降水的大 致情况以及可能出现的洪涝灾害的.

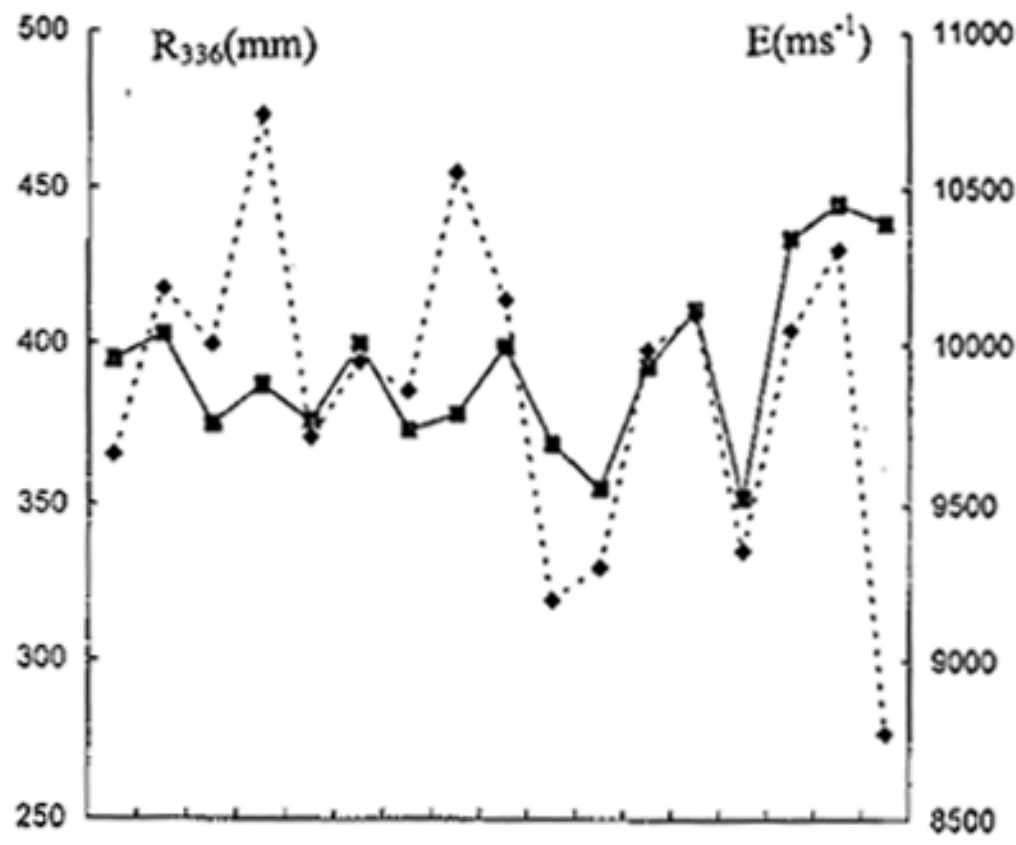

图 1 1979-1995 年全国 336 个站 6-8 月平均降水量 $R_{336}$ （实线）与东半球夏季（6-9 月） 850hPa 越赤道气 流总量的 $\mathrm{E}$ 值（虚线）逐年演变图

Fig.1 The inter-annual change chart of the $R_{336}$ (solid line) and E (dashed line) during 1979-1995

\section{2 非亚支宏观系统与洪涝灾害}

在 1987 年出版的《降水问题》一书中，李宪之正式提出了 “半球间宏观系统” 的概 念. “宏观系统” 也可称做 “宏观气流系统” 或 “宏观天气系统”, 它是指从一个半球（冬 半球）的中、高纬度穿过赤道地区，到达另一半球（夏半球）的中、高纬度呈大 “S” 形的 大规模的气流活动或一系列相联系的天气系统, 并指出影响中国天气与气候的主要是澳亚 地区的半球间宏观系统, 也可称做 “非亚支宏观系统”. 因为这种宏观系统最不稳定，所含 
浴度最强最大. 在其影响下, 如果再有其他有利条件, 便致成强烈降水, 还可以产生气旋以 致强烈热带气旋或龙卷风. 他并且给出了 8 条分别从南、北半球出发的 “宏观系统” 的大致 路径及对世界天气气候可能产生的影响 ${ }^{[9]}$. 图 3 给出了南半球冷空气活动的主要方向.

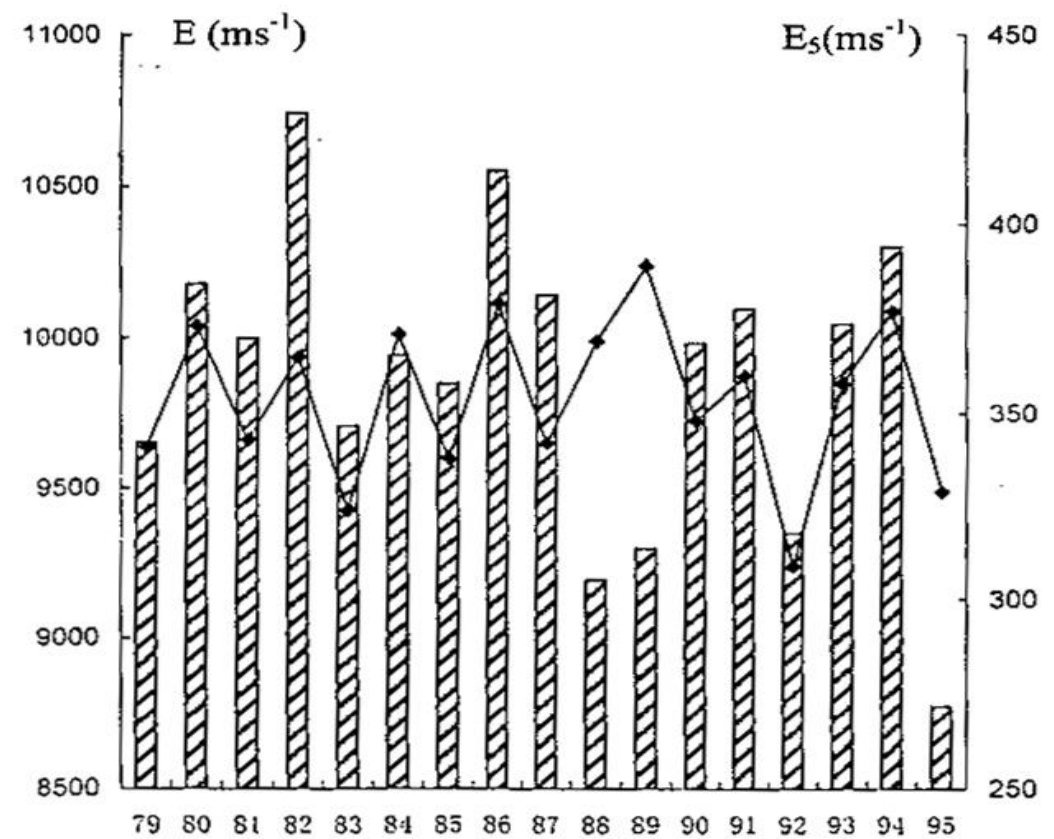

图 2 1979-1995 年期间 $\mathrm{E}_{5}$ (折线) 与 $\mathrm{E}$ 值（直方图）年际变化相关图（细实线为 $\mathrm{E}_{5}$ 值）

Fig.2 A correlative chart of the relationship between the $\mathrm{E}_{5}$ (solid line) and $\mathrm{E}$ (histogram) during 1979-1995

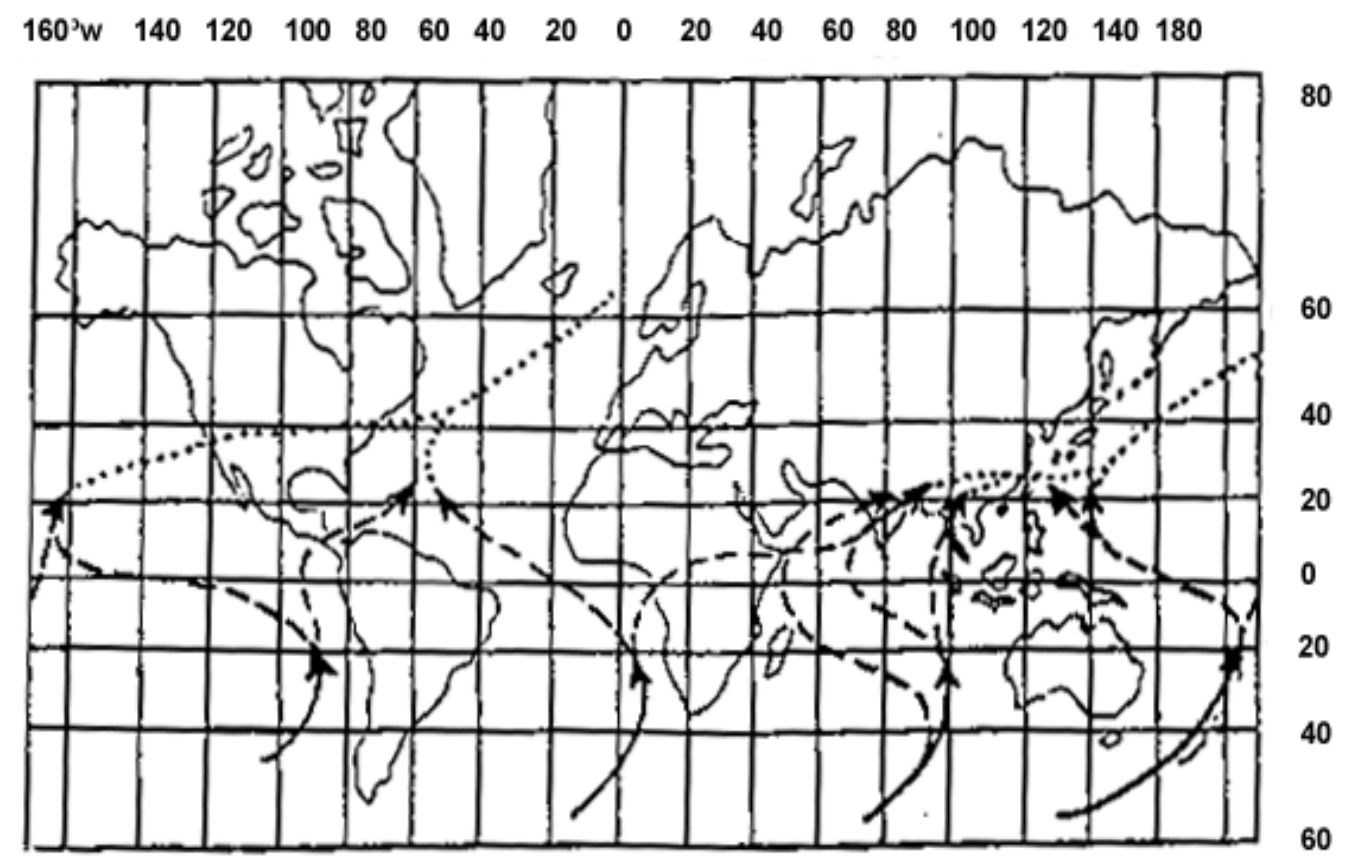

图 3 南半球冷空气活动的主要方向 (取自《降水问题》一书, 但做了部分修改)

Fig.3 Several principal moving directions of the Southern Hemisphere cold air 
a:1998-6-12-27 850hPa 风场

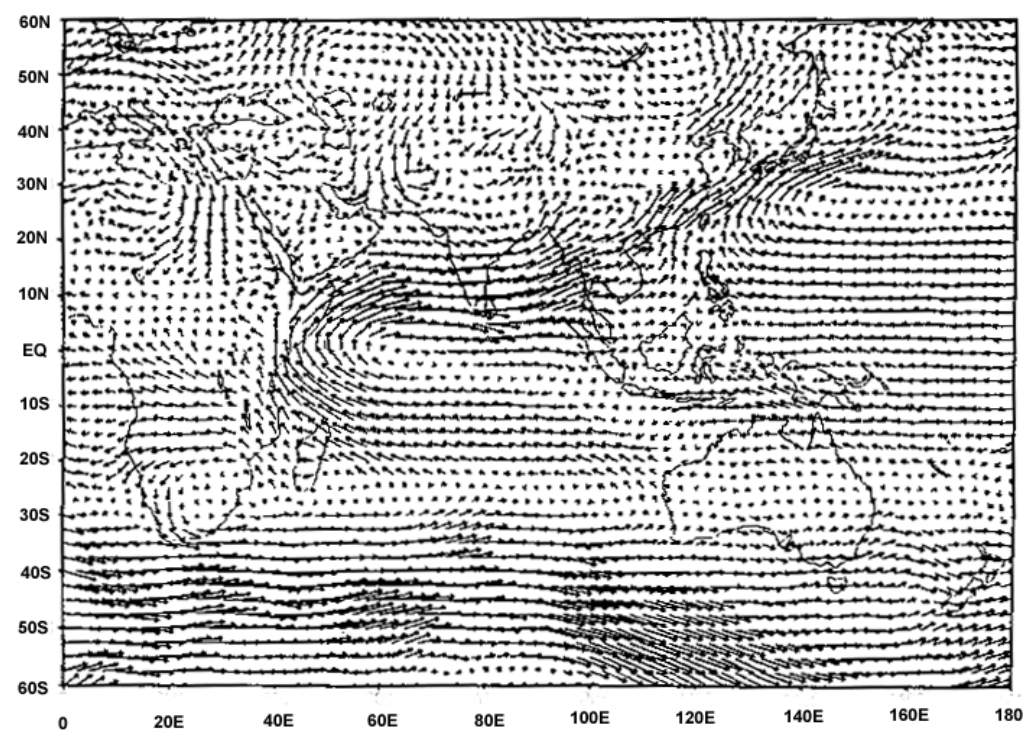

b: T106 850hPa 风场 1999-6-15-19

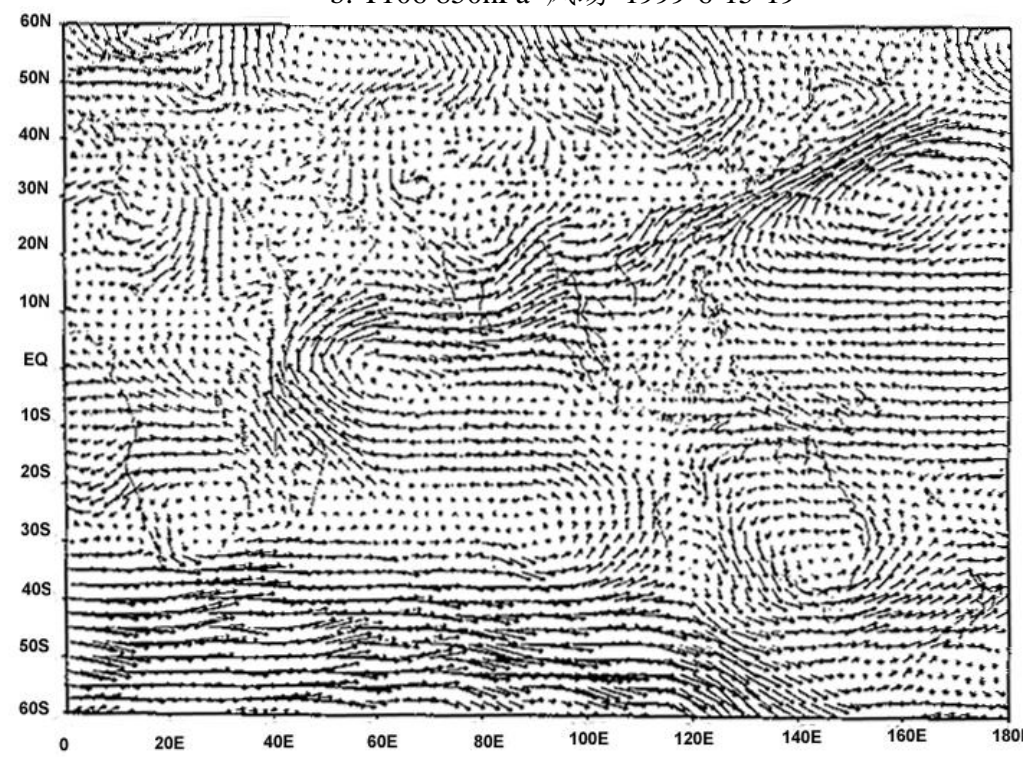

图 4 长江中、下游地区多雨时段的 1998 年 6 月 12-27 日（a）及 1999 年 6 月 15-19 日 (b) $850 \mathrm{hPa}$ 东半球合成风场图

Fig.4 The resultant wind field at $850 \mathrm{hPa}$ in the Eastern Hemisphere during the period of in storm over the middle and lower reaches of Yangtze River 12-27 June 1998(a) and 15-19 June 1999 (b) respectively

对中国大水年的 1991、1996、1998 及 1999 年每年两个中国大陆多雨时段的 $850 \mathrm{hPa}$ 流场进行了合成分析，结果发现它们都有着非常一致的流场形势：气流自南半球的中高纬 度流向非洲东岸，在索马里处穿过赤道后，在科氏力作用下转为西南季风，一部分自阿拉 伯海穿过印度次大陆、孟加拉湾及横断山脉进入我国云贵川及青海、西藏、甘肃、宁夏等 
省区; 另一部分自南海北部进入我国江南及江淮、东北、朝鲜半岛中、南部并进入日本列 岛, 在沿途造成持续性降水及特大暴雨.图 4a,b 分别给出我国多雨时段的 1998 年 6 月 12-27 日及 1999 年 6 月 15-19 日 850hPa 东半球合成风场.从图可以看出, 这些系统的气流有着相 似的流型.这说明长江流域的暴雨和洪水是可以及时地进行监测和预报的.如果在 “宏观气 流系统” 的上游地区施行人工降雨, 在需要雨水的地区增加降水, 就可以减轻洪涝灾害, 使其转化为可利用的水资源.

\title{
4 结论
}

长江流域的特大暴雨及洪涝灾害形成原因，主要是由于越赤道气流的异常以及 “宏观 气流系统”的一再侵袭所造成的. 长江流域的暴雨及洪灾是可以监视和预报的.气象与地球 物理综合法”1998-2002 年的预报试验，具有一定的预报能力. 此外在长江流域多雨时段期 间可以在 “宏观气流系统”的上游地区施行人工降雨手段，化下游地区的洪涝灾害为可利 用的水资源.

\section{参 考 文 献}

梁必骐等. 热带气象学. 第一版, 广州：中山大学出版社, 1990:66-67 中国气象科学研究院. 中国近五百年旱涝分布图集. 第一版, 北京: 地图出版社, 1981

Sjan-zsiLi. Die Kä1teeinbrüche in 0stasien. Inaugura1-Dissertation, Philosophischen Fakultät der Friedrich Wilhelms-Vniversität zu Berlin, 8. Februar, 1935

李宪之. 降水问题. 第一版. 北京: 海洋出版社, 1987

李曾中. 中国汛期涝灾 “强信号” 研究. 见: “贺李师文集” 编委会. 寒潮、台风、灾害一庆贺李宪之教授九十五华诞文集. 北京:气象出版社, 2001:516-524

李曾中, 楼光平. 北半球夏季风时期东半球越赤道气流通道研究. 大气科学, 1987, 11（3): 313-319

李曾中. 越赤道气流与中国天气关系的初步统计分析.气象, 1986, (4):11-14

李曾中, 钱传海, 孙除荣. 1991 年江淮暴雨与越赤道气流关系初步分析. 气象学报, 58（5）:628-636

李宪之. 减轻几种主要自然灾害的途径. 见: “贺李师文集” 编委会. 寒潮、台风、灾害一庆贺李宪之教授的九十五华诞文

集. 北京:气象出版社, 2001:369-374

\section{The Cause of Flooding in the Yangtze River Valley and the Measure for Disaster Reduction}

\author{
LI Zengzhong \\ (Chinese Academy of Meteorological Sciences, Beijing, 100081,P.R, China)
}

\begin{abstract}
The cause of storm rainfall and flooding in the Yangtze River Valley was analyzed in this paper. It was closely connected with the anomalies of the Cross-Equatorial Flow- (CEF) and the influence of African-Asia "Large-scale Synoptic Systems between Two Hemisphere". At the same time, it is pointed out that not only the storm rainfall and flood disaster in the Yangtze River Valley could be predicted in time, but also could be controlled and reduced by weather modification.

Keywords: Storm rainfall and flooding disaster, Cross-Equatorial Flour- (CEF), African-Asia "Large-scale Synoptic Systems", the measure for reducing disaster
\end{abstract}

